\title{
The work of transnational forensic medicine experts in colonised zones: the Palestinian case
}

\author{
Suhad Daher-Nashif Qatar University-Doha, College of Medicine, \\ Qatar \\ suhadh@hotmail.com; snashif@qu.edu.qa
}

\begin{abstract}
This article aims to shed light on the post-mortem practices for Palestinian dead bodies when there is suspicion of human rights violations by Israeli military forces. By focusing on the case of Omran Abu Hamdieh from Al-Khalil (Hebron), the article explores the interactions between Palestinian social-institutional agents, Israeli military forces and international medico-legal agents. Drawing on ethnographic and archival data, the article explores how the intersectionality between the various controlling powers is inscribed over the Palestinian dead bodies and structures their death rites. The article claims that inviting foreign medico-legal experts in the Palestinian context could reveal the true death story and the human rights violations, but also reaffirms the sovereignty of the Israeli military forces over the Palestinian dead and lived bodies.
\end{abstract}

Key words: autopsy, transnational pathologists, Palestinian martyrs, occupation, social practices

\section{Introduction: the Palestinian political body and forensic medicine}

Some anthropological studies have examined the social-political formation of the Palestinian body, largely focusing on symbols and meanings of the lived body in political contexts. ${ }^{1}$ These studies have mainly referenced the Israeli occupation period, overlooking the historical developments leading to the Palestinian body's formation. They analyse the body's existence as formed by the relationship between the individual-social body and the political body, a perspective first offered by Nancy Scheper-Hughes and Margaret Lock. ${ }^{2}$

This relationship between the social-political context and the social-political body has been discussed in studies on the Palestinian lived body ${ }^{3}$ and Palestinian death. ${ }^{4}$ Meira Weiss was the first anthropologist to extensively explore how Palestinian dead bodies have become sites for Israeli militaristic and colonial practices within the context of the Israeli forensic medicine system. ${ }^{5}$ In her research, she examines autopsy practices conducted on dead Palestinian bodies at the Israeli National Center of Forensic Medicine (NCFM), known as Abu-Kabir, ${ }^{6}$ especially 
during the first Intifada in 1987. In her book Over their Dead Bodies (2014) Weiss says: 'In the first Intifada, the [Israeli] army allowed the centre [NCFM] to harvest organs from Palestinians using a military regulation that an autopsy must be conducted on every killed Palestinian. Autopsies were accompanied with organs harvest. The Skin Bank and other organ banks used these organs for transplantation, research and teaching medicine. Many of the centre workers referred to the first intifada (1987-1993) as the "good days", when organs harvesting was conducted consistently and freely, compared to other periods' (p. 149). Following Weiss's work, Daher-Nashif examined both Israeli and Palestinian post-mortem practices with regard to Palestinian dead bodies within the context of the Palestinian forensic medicine system from the 1993 Oslo Accords until today. ${ }^{7}$ She claims that Palestinian corpses were used by the Israelis and Palestinians as an arena for restructuring the coloniser-colonised relationships. Palestinian dead bodies were used by Israelis to further oppress the bodies of living Palestinian, and were used by Palestinians to resist the Israeli colonial power.

Ethnographic research on autopsies draws heavily from Foucault's conception of biopower to understand the numerous and diverse techniques the sovereign entities use to subjugate bodies and control populations. ${ }^{8}$ Whether power is conceived in classical terms, as the power of the sovereign to control and govern the 'other' subject, or, as Foucault maintains, as a disciplining force dispersed throughout society and implemented by many institutions, science and technology are indispensable in expressing and exercising power and violence. Foucault considers the role of the body, saying: 'The body is also involved in the political field; power relations have an immediate hold upon it; they invest it, mark it, train it, torture it, force it to carry out tasks, to perform ceremonies, to emit signs. ${ }^{\prime 9}$ This idea was further developed in Judith Butler's Bodies That Matter, when she explained how the body is re-signified, reformed and restructured by the apparatuses of controlling powers. ${ }^{10}$ This reformation is addressed by Achille Mbembe in his 'Necropolitics' when he analyses how Israeli sovereignty and colonisation are embedded in the ability of the coloniser to decide upon who deserves to live and who deserves to die. ${ }^{11}$ Daher-Nashif (2018) claims that within the Palestinian context the issue goes beyond this decision and reaches the coloniser's decision regarding how the colonised should die and how their body should appear or disappear following their death. ${ }^{12}$

Mbembe (2003) views Israel's decisions regarding who deserves to live and who deserves to die as being at the centre of its colonial practice. ${ }^{13}$ Part of Mbembe's assertions are based on Foucault's notion of governmentality, which is the power to govern, control and guide the conduct and the capacity of others and the self when combined with the political economy and the security of the population. ${ }^{14}$ Biopower, governing the living and the multiple practices in the context of dying, ${ }^{15}$ stands at the basis of these governmental powers. In settler-colonial regimes, the body is re-signified as a political body and becomes an arena for restructuring the colonisation dynamics. Judith Butler (2004) details these dynamics in her analysis of how the Israeli military system otherises not only living Palestinians, but also the death of Palestinians, considering it as others' death, undeserving of sorrow or grief. ${ }^{16}$ Although several studies have examined how Palestinian bodies are affected 
on a daily basis by the political domain in which they live, ${ }^{17}$ very few studies have examined the socio-political inscriptions on the Palestinian corpse's flesh and body during its post-life existence. ${ }^{18}$ This article explores the colonisation powers practised by the Israeli military over dead Palestinian bodies when a martyr's family or a human rights organisation may request having a foreign medico-legal expert present for an autopsy to investigate and/or to have a second examination of the body. In this case, three controlling agents of powers, namely Israeli, Palestinian and foreign pathologists, are involved in writing the autopsy report or the death story.

\section{Forensic medicine and conducting autopsies in Palestine}

The scholarly literature on forensic medicine within Palestinian society is scarce. In general, Israeli, Palestinian and Jordanian studies point to the British Mandate (1921-48) as the beginning of forensic medicine in Palestine. ${ }^{19}$ Very few studies discuss the fact that autopsies and post-mortem examinations were performed during the Ottoman Empire, especially at the end of the nineteenth century and the beginning of the twentieth century. ${ }^{20}$ Practices changed from one period to another in accordance with changes in political and legal processes in the Arab world in general and in Palestinian society in particular. Following the Ottoman Empire governance (1516-1917), the British Mandate established a system of coroners through which the new regulations and rules were imposed on the local community in criminal cases. ${ }^{21}$ During the British Mandate there was a requirement that deceased Palestinians should undergo autopsies. This process was governed by English common law and, in cases where the death appeared to be unnatural or due to suspicious circumstances, autopsies were performed by British government physicians. ${ }^{22}$ According to Al-Hadidi and Hamdi, ${ }^{23}$ on 1 September 1926 Mandatory forces enacted the JudgesInvestigators Law (no. 13), otherwise known as the Coroner Ordinance. This law consisted of eight clauses that outlined medico-legal practices over Palestinian dead bodies throughout the period of the British Mandate.

However, the events of 1948 ruptured legal continuity in the region - specifically, the connection between the West Bank and the Gaza Strip. When Jordan annexed the West Bank it formally extended its own laws to that area. ${ }^{24}$ The limited research that exists on forensic medical practices within the Palestinian context, especially in the West Bank, during that period indicates that, in criminal cases, Palestinian corpses were handled in the same way as Jordanian corpses. ${ }^{25}$ The Jordanian forensic investigation system operated according to European standards, whereby the authority to order an autopsy lay with the attorney general, who was assisted by forensic doctors acting on behalf of the health bureau. ${ }^{26}$ On the other hand, the legal system in the Gaza Strip remained virtually the same from 1948 to 1967. Egypt did not annex the territory and, aside from a few military orders, it maintained the common law that had previously dominated. The outcome was three different legal systems: one in the West Bank, another in the Gaza Strip and the Israeli law imposed on Palestinians living within Israeli state borders. ${ }^{27}$ Autopsies were performed on the bodies of the third group of Palestinians at the Israeli NCFM, established in 1954 
by Heinrich Karplus. Previously (1948-54), pathologists in hospitals had performed post-mortem examinations and autopsies.

Information on forensic medicine during Jordan's pre-1967 West Bank rule is obscure and scarce, but interviews with doctors who worked in the Jordanian system during this period indicated that there were cases in which the attorney-general decided if there was a need to examine the body, and this examination was performed by a pathologist or an ordinary doctor and not a resident forensic doctor. ${ }^{28}$ In Jerusalem, doctors conducted autopsies at the Austrian Hospice following the attorney-general's decision. ${ }^{29}$

From 1967, when Israel occupied the West Bank, until the 1993 Oslo Accords, autopsies of Palestinian corpses were performed at the Israeli NCFM. Most of these autopsies were performed by Israeli pathologists, and in a few cases families or a human rights organisation were allowed to bring in a foreign expert. The Israeli NCFM provided medico-legal assistance and transferred their findings to three main Israeli authorities: the Ministry of Police, the Defence Forces and the Ministry of Health. ${ }^{30}$ This era ended with the Oslo Accords in 1993, when the Palestinian Liberation Organization (PLO) returned to the Palestinian lands as the Palestinian National Authority (PNA) and an era of autonomous governance began. One of the first decisions of Yasser Arafat, the first president of the PNA, was to establish a forensic medicine centre. ${ }^{31}$ At the beginning, the Palestinian Forensic Medicine System (PFMS) functioned within the hospitals, but in 1996 two Palestinian forensic medicine institutes (PFMI) were opened, one in the West Bank at Al-Quds University in Abu-Dis ${ }^{32}$ and a second one in the Gaza Strip at Al-Shifaa' Hospital.

It is important to note that each period and each governing power used the Palestinian dead body as a tool to empower their control over the local community. Developments and transformations in the medico-legal practices, alongside historical changes in Palestine, are a reflection of the social and political developments that determined laws and affected medico-legal procedures at different colonial periods. Changes in forensic medicine practices within Palestinian society have also reflected the different approaches maintained by each governing power. ${ }^{33}$ Joint autopsies, through which transnational pathologists accompanied Palestinian and Israeli pathologists, are part of the conflict that inscribed over the Palestinian dead body.

\section{Joint autopsies and foreign pathologists' intervention}

The first autopsy conducted jointly by Jewish, Arab and British pathologists took place in $1929 .{ }^{34}$ Hiss et al. noted the following of this joint autopsy:

On August 24 of that year, 56 Palestinian Jews were murdered by the local Arab population of Hebron; the bodies were buried by the British authorities after external examination by a Mandatory police surgeon. Because of rumours of mutilation and sexual assault of the victims before death, the Mandate authorities ordered exhumation and revision of the previous examination to be conducted by a joint team of British, Arab, and Jewish medical graduates. Two weeks later, 20 of the bodies were 
exhumed. Since the examination did not disclose any sign of premortal torture, the inquest was closed. This is probably the first instance of collaboration between occupation authorities and medical experts on behalf of the local population. ${ }^{35}$

Joint autopsies were performed again sixty years later, during the first Palestinian Intifada (uprising) in 1986, and continued through the second Intifada in 2000 and subsequent years. During the first Intifada transnational forensic medical experts became involved for the first time in cases referred to them by human rights organisations or Palestinian families. During this period, in October 1988 for example, an external expert autopsied Ibrahim Al-Umtur, a 31-year-old Palestinian and father of five children. Testimony from fellow detainees indicates that Al-Umtur, who was arrested by Israeli security forces, was removed from an army bus at Al-Dhahriya detention centre, blood streaming down his face, while screaming 'Allahu Akbar! ${ }^{36}$ I am Ibrahim Al-Umtur! They are beating me to death! Detainees, witness!!!' ${ }^{37}$ On 20 October, during a routine check by an army corporal, Ibrahim was found dead. The first autopsy was conducted by Israeli authorities ${ }^{38}$ shortly thereafter and described the cause of death as 'mechanical asphyxiation from hanging'. A second autopsy, performed at the request of the family and in the presence of Scottish pathologist Dr Derrick Pounder of Dundee University, found that the death was caused by 'asphyxiation due to ligature pressure on the neck'. Dr Pounder concluded: 'It is my view that already in restraints, teargassing in a cell when already in restraints, probable physical assault when already in restraints, the administration of drugs, the probable deprivation of sleep, the isolation from other detainees and likely lack of facilities for personal hygiene, taken together constitute prima facie evidence of cruel, inhuman, and degrading treatment. ${ }^{39}$

Previous to Al-Umtur's death, and following the death of five detainees in the course of a single week in August 1988, human rights activists attempted to establish oversight and investigatory mechanisms, with some success. Among other things, they advocated investigation of all deaths by or in the presence of independent foreign experts.

Another example is the case of Khaled Shaykh Ali from Gaza. Khaled died in the interrogation section of Gaza prison on 19 December 1989. The Israeli authorities claimed that the cause of death was a heart attack. However, a subsequent autopsy, conducted upon the request of $\mathrm{Al}-\mathrm{Haq},{ }^{40}$ a Palestinian human rights organisation, and Physicians for Human Rights Israel (PHRI) in the presence of a pathologist from New York, indicated that he died from internal bleeding following blows to the abdomen. ${ }^{41}$ This was not an isolated incident.

In other cases, families, together with the human rights organisations, continued to invite independent pathologists to perform and witness autopsies and provide consultation. Inviting foreign pathologists has continued following the Oslo Accords, throughout the second Intifada (Al-Aqsa uprising) in 2000 and until this day. Occasionally, upon the request of the deceased's family or the Palestinian attorney-general, a Palestinian pathologist has travelled to Abu-Kabir and participated in an autopsy. In those cases, the Palestinian pathologist crossed the border between the Occupied Territories and Israel, a process that takes place in 
accordance with Israeli permission. The Palestinian pathologist, like the dead Palestinian, becomes a medium for maintaining Israeli institutional and colonial control over Palestinian bodies.

All joint autopsies that were performed were done so following approval from the Israeli side, under its control and in its forensic medicine institute. This shows that even when a foreign expert is invited to perform a second or even a first autopsy of a Palestinian body, Israel's status as a sovereign power over the Palestinian dead body is still empowered. That is, inviting a foreign expert empowers Israel's sovereignty over the Palestinian corpse, and can be considered as part of its colonial inscriptions over the Palestinian dead body. Allowing the invitation and participation of a transnational expert may create the impression of Israel as a human rights state, despite the first violation. This double role of violating the rights of the dead and then supporting revealing the truth reflects Israel's power over which and how Palestinians should die. That is to say, when a Palestinian corpse undergoes a medico-legal examination in the Israeli forensic medicine institute in the presence of foreign and local Palestinian pathologists, the body is marked with political meaning in relation to the occupation and its political and bureaucratic agencies.

In the next section I present the story of Omran Abu-Hamdieh as a case in which his dead body became an arena for the colonial apparatuses' inscriptions. I received the data on Omran's story through ethnographic fieldwork conducted between 2004 and 2009. During that period, foreign experts dissected several dead Palestinian bodies at the Israeli NCFM. In all cases, these were considered to be deaths on Israeli territory. On the Palestinian side, there is territory but no sovereignty, therefore no Israeli has ever been dissected in the PFMI, even if he/she died on Palestinian territory or within the borders of Zone A. ${ }^{42}$

\section{The case of Omran Abu-Hamdieh}

Omran was 17 years old when he died. While the Palestinian side claims that he was beaten to death by Israeli soldiers, the Israeli authorities denied any and all responsibility for his death. His family, in conjunction with Al-Haq, invited Danish pathologist Jorgen L. Thomsen to perform the autopsy and write a detailed medical report outlining the probable cause of death. ${ }^{43}$ Lena Johansson, a legal researcher working in Al-Haq, outlined this case in detail in 2003.

Omran's story took place in the old city of Al-Khalil at around 8:00 pm on 30 December $2002 .{ }^{44} \mathrm{He}$ was with friends on the street; this was despite a curfew placed on the area by the Israeli military, whereby residents were forbidden to leave their homes and the Israeli army was monitoring all movements. While walking down the street, Omran and his friends were stopped by four border police in an Israeli army Jeep. The border police checked the men's identity cards, forced Omran into the Jeep, and then left the area. Knowing that Palestinians taken by Israeli military personnel are often beaten, Omran's friends followed the Jeep on foot. Soon thereafter, they found Omran's beaten and bruised body lying in the street. They immediately took him to the local hospital. However, he was pronounced dead upon 
arrival. Approximately forty minutes passed between when Omran was seized by the border police and the arrival of his body at the hospital. ${ }^{45}$

Following Omran's death, Al-Haq fieldworkers collected testimony from witnesses. One statement documented as follows:

At about five past eight in the evening on the 30th of December 2002, I was standing in front of my house, which is situated in the neighbourhood of the Tareq Ben Ziad School in the city of Hebron. This area had been placed under a continuous curfew since around the 15th of November 2002. I saw an Israeli border police Jeep speeding south towards an area known as Fahes. There are a large numbers of stores and factories in this area.

Suddenly I saw one of my friends, Fallah Abu Hamdieh (23) running in the same direction the Jeep had gone. I asked him what was the matter, and he said that he was following the path of the army, which had taken Omran. He continued, and I followed with him and others who were with him. It is known that soldiers usually beat the men they take to the Fahes area. Previously, I had heard of a large number of people that had been beaten and left in the streets in uninhabited areas where it was hard for the men to reach either the hospital or their houses. I followed so as to help Omran after they beat him. I knew Omran; he was about 17 years old.

We followed the road until we reached the Fahes area. There were still Israeli soldiers in the area, so we continued carefully in order to ensure that none of us would become a new victim at their hands. When we were close to the gas station in Fahes we saw a body, but it was hard to see since it was very dark. We could see the body from the reflection of a light shining from behind it. We hurried towards it; there was nothing else in the street. When we got there, we saw that the body was that of Omran. He didn't move and when we came very close we saw blood coming from his mouth and nose. I screamed in order wake him up, but he didn't move. We called for help and approached a car with Israeli plates. The driver was a young man from Hebron. He stopped and we put Omran in his car. When we arrived at Muhammad Ali Muhtaseb hospital, which is about half a kilometer away, we exited the car and carried Omran into the hospital. Doctors and nurses hurried to help him in the emergency room, and we went out of the room. A doctor came out after less than five minutes. He looked at us and asked who were with him. We were four young men. The doctor said that he had passed away. This news was an enormous evil. We argued with the doctor and demanded that he conduct an examination to make sure, but there was no hope. Omran was dead. ${ }^{46}$

This statement and others taken from witnesses to this incident highlight some of the social and political issues that frame the narrative surrounding Omran's death. These statements are also part of structuring Omran's existence as dead. They express the ways in which Palestinians experience incidents such as these.

Omran's death was widely publicised in the Palestinian and Israeli media. Due to the attention generated by this case, the Israeli military decided to perform an autopsy. However, in order to perform the autopsy his body had to be exhumed and permission needed to be granted from his family. Initially they declined this 
request ${ }^{47}$ because he's a martyr. As a martyr, social norms and political meanings dictate that a martyr's body is sacred. Accordingly, the body is buried fully clothed and without undergoing the ritual purification mandated by Islamic law in the case of death under 'normal' circumstances. ${ }^{48}$ The manager of the PFMI explained it as such: 'Autopsies for martyrs are seldom performed ... People generally refuse autopsies due to their religious faith ... People think that the body is sacred and it is forbidden to perform an autopsy on it. I can shout until morning that the soldier killed me but, for the legal system, this is meaningless until I have material evidence, which, in these cases, can only be obtained by performing an autopsy. ${ }^{49} \mathrm{He}$ reiterated that families generally refuse autopsies for loved ones, due to their Islamic religious beliefs.

In Omran's case, the family initially refused an autopsy on national and religious grounds. However, 'following intervention by Al-Haq and lengthy discussions with the Mufti of Hebron, ${ }^{50}$ Omran's family eventually relented. They gave Al-Haq power of attorney; this permission was then transferred to the Israeli human rights organisation B'Tselem, ${ }^{51}$ which submitted the case to the Police Internal Investigation Department within the Israeli Ministry of Justice. This process eventually led to the autopsy being performed. ${ }^{52}$ At the family's request, and through the facilitation of Al-Haq and B'Tselem, Professor Jorgen Thomsen from the Centre for International Forensic Assistance in Denmark was brought in as a consultant to witness both the exhumation of the body and the autopsy.

On 26 January 2003, around midnight, Omran's grave was opened and his body was taken to the Israeli NCFM. Both Israelis and Al-Haq preferred to exhume the body late at night. The Israelis were concerned that it could trigger confrontations with local Palestinians, as the process was very much tied to the occupation. Al-Haq worried that it could trigger sensitivities around exhuming a dead body. Thus, both preferred a late-night exhumation. This indicates the importance of time-space for colonial and social inscriptions over the Palestinian corpse. Israel's sovereignty over the Palestinian corpse is reflected in its ability to decide upon when, how and who is allowed to see Omran's body. It is important to note here that Israel structures the time-space of the living Palestinian as well, by designing a time-space fragmented by military checkpoints, a separation wall and bureaucratic restrictions through which Palestinian movement and lives are controlled and observed. ${ }^{53}$ Omran's autopsy was performed the day following the exhumation, in the presence and with the of Professor Thomsen. He described the exhumation and autopsy as follows:

At the request of Al-Haq and B'Tselem I travelled to Israel from the 26th to 28th January 2003 in order to attend the exhumation and autopsy of the above [Abu Hamdieh]. On the 26th January 2003, I went in a car to Hebron together with two lawyers affiliated with Al-Haq. The exhumation was supposed to take place at 8:00 pm and we arrived at the military camp just outside of Hebron a little after 7:00 pm, we waited for a couple of hours and then the gate was opened to Hebron, and we waited another couple of hours close to the churchyard before the Israeli army arrived shortly before midnight [...] Some of the relatives used sledgehammers to gain entry into the sarcophagus where the deceased was buried. It only took a few minutes to create a 
suitable opening from where the deceased was taken and brought to an ambulance in which he was taken to the national centre of Forensic Medicine in Tel Aviv. The body was swathed in cloth and the cloth was removed at the time. ${ }^{54}$

Professor Thomsen also described the process of post-mortem examination as follows:

I arrived at the National Centre of Forensic Medicine on Monday 7th January 2003 at 9:45 a.m. I met Doctor Yosi [a pseudonym]. He informed me that he was going to perform the autopsy and that I would be welcome to assist and suggest examination as much as I wanted. The post-mortem examination took place with the help of a laboratory assistant. The cloth had been opened before I arrived so that the face and a part of the body were visible. The identity was established by the relatives. Doctor Yosi informed me that he had also taken blood samples from the mother and another relative in order to compare them with samples taken from the deceased using a DNA technique. The body was that of a young boy in a rather advanced state of decomposition. The head of the body and even the extremities were swollen with dark discoloration. There were scattered dark discolorations giving a suspicion of bruising which was only partly confirmed (vide infra). Doctor Yosi undertook an examination of the internal organs. This examination did not reveal any sign of existing disease, and the organs were all normal except that we did not succeed in locating the left testis. $^{55}$

The above description reveals the agents of power over the dead Palestinian body - a foreigner and an Israeli, but not a Palestinian. Sometimes the family requests that a Palestinian pathologist be present even when the autopsy is conducted at the Israeli Forensic Medicine Institute and the Israeli Institute writes the report. The fact that the Israeli authorities can override the wishes of the grieving family is another indication of Israel's sovereignty over Palestinian bodies.

Professor Thomsen's report seemed to indicate that Omran's death was due to violence. He noted that there was an evidence of physical violence. He wrote:

The right temple had a large hematoma due to bruising. There were small bruises in the back of the head. There was a large fracture in the back of the head; on the left side of the back there was a large bruising with a hematoma going deep into the muscles; there were abrasions on the lower part of the back and there was also a deep hematoma in the right leg [...] There were furthermore fractures with many lines on the vault and the base of the skull. These fractures were the result of heavy blunt violence. It could not be determined if they were the result of a fall on the back of the head or a blow with a blunt instrument. Due to the pattern of the fractures it was more likely to be the result of a fall than that of direct blow. ${ }^{56}$

The fact that the autopsy was conducted within Israel and not at the Palestinian centre indicates that Israel empowers its colonial practices over the dead Palestinian 
body. Accordingly, this case points to the intrusion of Israel into the Palestinian Authority's sovereignty.

On 18 April 2003 the border policemen involved in Omran's incident were remanded when Israel opened an investigation into the case. On 2 September 2008 the Jerusalem District Court found Shahar Botbeeka and Denis Al-Hazoob, two Israeli border police officers, guilty of the kidnapping and homicide of Omran. ${ }^{57}$ According to the charge sheet, four Israeli border policemen abducted him and one (Al-Hazoob) photographed the whole incident. Botbeeka beat Omran a number of times and, with another policeman, opened the back door of the Jeep and ordered Omran to jump out of it while it was still moving. When he refused, the two policemen threw him from the Jeep. The driver heard the blow to Omran's head and screamed 'he's dead, he's dead', but continued driving, while Omran was left to die at the side of the road.

\section{Final remarks}

The process of formulating Professor Thomsen's autopsy report and its accompanying documentation is integrally connected to the writing of the death and the narrative that surrounds its circumstances. Opening the body to read it, sampling the organs and then closing the body are ways in which the Israeli military forces, alongside the medico-legal authorities, exercise sovereignty over the flesh of Palestinian corpses.

A question that may be raised is why was the independent forensic expert not Palestinian? Inviting an international expert weakens the sovereignty of the PNA. This highlights the difficulties Palestinians face in being active agents in managing their own death issues. The absence of a Palestinian voice situates the Palestinian state as being both present and absent in this process, i.e. a present-absent status.

It is also important to examine the rationale employed by the Israeli authorities in permitting the re-examination of this case and others by transnational experts. In the case outlined above, Israel gave Professor Thomsen permission both to enter the Occupied Territories to witness the exhumation and to participate in the autopsy within Israeli time-space. Although a Palestinian had died under suspicious circumstances, the Israelis approved an autopsy, the Palestinians agreed, an external expert was invited to participate and Israel gave this person full access to the process. The Israeli position is counter-intuitive; they seem to want to reveal the truth and pursue justice against their own interests. In this instance and others, when the accused are found guilty they tend to be portrayed as outliers and as individuals who acted of their own volition, thus absolving the Israeli State, including its political and military arms, of guilt.

International law is also relevant in incidents such as these. The West Bank and the Gaza Strip have been occupied by Israel since 1967. According to international law, such a situation falls under the rubric of the Fourth Geneva Convention Relative to the Protection of Civilians in Time of War (1949). The Convention, which outlines the rights and duties of the occupying power, is meant to provide protection for civilians in situations of armed conflict. ${ }^{58}$ Since 1967, Palestinians have been 
living under the authority of an occupying power; accordingly, they should be considered protected persons in accordance with the Convention. Therefore, taking into account Israeli guilt in this case, the Israeli soldiers committed the following violations:

- wilful killing. Any murder of a civilian that is intentional or is not justified by military necessity qualifies as a grave breach of the Convention (Article 147) and as a war crime. In international criminal law, intent is present where there is a demonstrated intention on the part of the accused to kill or to inflict serious injury or where one displays reckless disregard for human life; ${ }^{59}$

- wilfully causing great suffering and serious injury to body and health; and

- torture and cruel treatment.

Omran's case also points to the intersection of international law, Israeli law and Palestinian law. On the one hand, Danish and Jewish-Israeli pathologists described the dead body through the lens of Western medico-legal discourse. On the other hand, social institutions (Al-Haq), religious institutions (the mufti) and community members participated in narrativising Omran's death with the permission of his family. Omran's case empowered each one of these institutions. Omran's dead body was re-signified by political and social-cultural powers. Both powers uphold controlling apparatuses in order to impose sovereignty and make the authority visible to the live bodies of society. This type of intersectionality is intensified in cases of political death and criminal proceedings. In Aporias, Jacques Derrida clearly explains how death and the space of burial are politicised:

I shall simply point out that it also includes a political dimension. It may even engage the political in its essence. In an economic, elliptic, hence dogmatic way, I would say that there is no politics without an organization of the time and space of mourning, without a topolitology of the sepulchre, without an anamnestic and thematic relation to the spirit as ghost [revenant], without an open hospitality to the guest as ghost [in English in the original], whom one holds, just as he holds us, hostage. ${ }^{60}$

Nadera Shalhoub-Kevorkian uses Derrida's note to explain how Palestinian lives in Jerusalem are militarised by Israel's surveillance over their daily lives and the thresholds of life, death and birth. In Security, Theology, Surveillance and the Politics of Fear, she claims that colonial powers were found to control the space of burial, but simultaneously, 'colonial surveillance cannot completely control the spectrum, ghosts of the colonised dead, who, in effect, continue to hold "hostage" and interrogate the very legitimacy of the coloniser. ${ }^{31}$ Shalhoub-Kevorkian argues that Israel positions Palestinian death as lawless by the law. A dead body is directly involved within the political scene and constitutes a tool to rebuild and reframe the colonised-coloniser relationship, on the one hand, and the authority of society, on the other hand.

From a religious perspective, two general Islamic attitudes regarding autopsies can be discerned. Some categorically reject autopsies because they believe that the human body is a gift from God and, accordingly, human beings must take care of 
and preserve that gift. This group bases its argument on Qur'anic verse 70 from Sura 17 (the night journey, Al-Isra'):

And we have certainly honored the children of Adam and carried them on the land and sea and provided for them of the good things and preferred them over much of what We have created, with [definite] preference.

They also based their beliefs on a Hadeeth ${ }^{62}$ of the Prophet Mohammad (pbuh) which states that: 'breaking dead bones is exactly like breaking the bones of a live body.63 A second Hadeeth is also often cited as a justification for opposition to autopsies: 'don't damn the dead so that you could damage the alive'. All three citations taken together point to an understanding of Islam whereby performing an autopsy would represent a distortion and disruption of God's creation. ${ }^{64}$

Others believe that an autopsy can be performed, but grant permission only when a number of conditions are met. In general, they stress the importance of conducting an autopsy in such a way as to ensure that there is no abuse or distortion of the corpse. Those who authorise and allow autopsies justify their views by arguing that Islam is a religion which is suitable and adaptable to every place and time and, as such, it must adapt to modernity and be sufficiently flexible to address social circumstance. They believe that if Islam permits the opening of the abdomen of a dead pregnant woman in order to save the life of the foetus, it must also permit the opening of a dead body in order to ensure justice, save truth and maintain social order. ${ }^{65}$ They mainly cite the religious rule: 'If there is a contradiction between two interests, you should choose the stronger. If there is a contradiction between two damages, choose the lighter one to prevent the harder one.'

The PFMI used the power of the religious discourse to legitimise autopsy and prevent social rejection. Immediately following the establishment of the PFMI, the manager asked the Palestinian main mufti, for a fatwa (ruling) granting the postmortem autopsy. ${ }^{66}$ The mufti gave such a fatwa twice: the first was on 2 August 2001, and a second, more detailed one, was given on 14 May 2004. Both fatwas dealt with two major and related issues: autopsy and organ transplantation. The Palestinian mufti declared that Islam takes into consideration developments in medicine and technology. Accordingly, it permits an autopsy that will contribute to the attainment of three goals: rendering justice, teaching students and transplanting organs to save the lives of others. He noted that his permission was conditioned upon respecting the corpse; this required conducting the autopsy in an appropriate place and without distortion of the body. Somewhat paradoxically, in support of his position he cited verse 70 from Sura 17, the same verse used by the rejecters for autopsy noted above. Accordingly, the same scriptures can be understood and applied in different ways to support religious views on respect for the body.

The Palestinian situation is congruent with that of other parts of the Arab world. Most Arab countries, including Egypt, Morocco, Tunis and other countries, have a fatwa for conducting autopsies and transplanting organs. ${ }^{67}$ These fatwas have 
been issued by nationally recognised religious authorities in order to prevent social opposition to the state's policies of control.

Since its establishment in 1994 the PFMI, for the most part, has been met with social opposition. Some have explained their resistance to it as being social and religious, while also mentioning political reasons embedded in the Israeli occupation. Politically, they believe that the establishment of the PFMI symbolises Israeli FMI practices prior to the Oslo Accords and the Accords themselves. They find any institution objectionable that was established through or because of the peace process with Israel, including the forensic medicine system. Furthermore, some Palestinians have viewed the work of the PFMI as a continuation of practices conducted by the Israeli NCFM. According to forensic medicine system workers, the vast majority of the Palestinian public have based their opposition to the PFMI on the belief that it contradicts the rules of Islam. The decision by the PFMI to approach the mufti is indicative of the interrelationship between state and religion in Palestine; each uses the other to promote and cement claims of authority and to produce and reinforce societal norms and attitudes. In relation to this, Talal Asad claims:

The enquiry, broadly speaking, has to do with the theme of power and religion - not merely in the sense in which political interests have used religion to justify a given social order or to challenge and change it (an important question in itself) but in the sense in which power constructs religious ideology, establishes the preconditions for distinctive kinds of religious personality, authorizes specifiable religious practices and utterances, produces religiously defined knowledge. ${ }^{68}$

Moreover, this analysis is indicative of a tendency or desire on the part of the controlling powers to achieve social order via medico-legal apparatuses and procedures. Islam in particular tends to connect and conflate religion and social order and/or norms in the context of death. ${ }^{69}$ Death empowers religious leaders because they establish their legitimacy and authority, in part, through the rituals and meanings they give to death. ${ }^{70}$ In the Palestinian case, death strengthens and reinforces linkages between religious institutions, the state and social structures. Thus, how do these institutions - religions and political alike - respond to autopsies performed by foreign experts? How does this process restructure and impact on such institutions and how does it influence their relationship with civil society?

Due to the complexity of the relations between occupation, national authority, religion and society, medico-legal practices over the Palestinian martyrs' bodies are a complete hybrid, nominal and complex. The practice of contracting with external international experts in the medico-legal arena, as in the cases mentioned in this article, plays a supporting role in maintaining a colonised-coloniser dynamic of power relations. Transnational pathologists who seek to promote a politics-free narrative around the death story are implicit in the construction of the real, very political death of the Palestinian state. 


\section{Suhad Daher-Nashif}

\section{Acknowledgements}

I thank Al-Haq Human Rights Organization for the data provided to me and the Forensic Medicine Institute of Al-Quds University for welcoming me into the Institute as an ethnographer.

\section{Notes}

1 Among others, see R. Kanaaneh, Birthing the Nation: Strategies of Palestinian Women in Israel (Berkeley, CA, University of California Press, 2002); L. Pitcher, 'The Divine Impatience: Ritual, Narrative, and Symbolization in the Practice of Martyrdom Palestine', Medical Anthropology Quarterly, 12:1 (1998), 8-30; J. Peteet, 'Male Gender and Rituals of Palestinian "Intifada": A Cultural Politics of Violence', American Ethnologist, 21:1 (1994), 31-49.

2 N. Scheper-Hughes and M. M. Lock, 'The Mindful Body: A Prolegomenon to Future Work in Medical Anthropology', Medical Anthropology Quarterly, 1:1 (1987), 6-41.

3 See, among others, S. Daher-Nashif and N. Shalhoub-Kevorkian, 'The Israeli Settler Colonial Desiring Machine', Journal of Palestine Studies, 26:104 (2015), 131-47 (in Arabic).

4 See A. Mbembe, 'Necropolitics', trans. L. Meintjes, Public Culture, 15:1 (2003), 11-40; J. Butler, Precarious Life: The Power of Mourning and Violence (London, New York, Verso, 2004); S. Daher-Nashif, 'Suspended Death: On Freezing Corpses and Muting Death of Palestinian Women Martyrs', Third World Thematics, 3 (2018), 179-95.

5 M. Weiss, The Chosen Body: The Politics of the Body in Israeli Society (Stanford, CA, Stanford University Press, 2002). See also M. Weiss, Over Their Dead Bodies: Power, Knowledge and the Institute of Forensic Medicine in Israel (Tel-Aviv, Resling Books, 2014) (in Hebrew).

6 Abu Kabir is the name of an occupied Palestinian village where the institute is located.

7 S. Daher-Nashif, 'History and Present-Day Practice of Forensic Medicine in Palestine: Body, Society and Science.' Jerusalem Quarterly Journal, 70 (2017), 75-95; S. Daher-Nashif, 'Instituting the Palestinian Dead Body', in L. Weeks (ed.), Death and Burial in Arabia and Beyond: Multidisciplinary Perspectives, London, Archaeopress-Society for Arabian Studies Monographs No. 10, pp. 363-8.

8 See, for example, M. Foucault, Discipline and Punish (New York, Pantheon, 1979); M. Foucault, Madness and Civilization: A History of Insanity in the Age of Reason (New York, Vintage Books, 1973); M. Foucault, The Archaeology of Knowledge (New York, Routledge, 1972).

9 Foucault, Discipline and Punish, 25.

10 J. Butler, Bodies That Matter: On The Discursive Limits of 'Sex' (London, Routledge, 1993).

11 Mbembe, 'Necropolitics'.

12 Daher-Nashif, 'Suspended Death'. 
13 Mbembe, 'Necropolitics', 25.

14 Foucault, 'Governmentality', in G. Burchell, C, Gordon and P. Miller (eds), The Foucault Effect: Studies in Governmentality (Chicago, University of Chicago Press, 1991), pp. 87-104.

15 Foucault, The History of Sexuality, Vol. 1: An Introduction, trans. R. Hurley (New York, Vintage Books, 1984), p. 39.

16 Butler, Precarious Life.

17 Among others, see E. Nashif, Palestinian Political Prisoners: Identity and Community (New York, Routledge, 2008); E. Nashif, Images of the Palestinian's Death (Doha, Arab Center for Research and Policy Studies, 2015) (in Arabic).

18 See Daher-Nashif, 'History and Present-Day Practice of Forensic Medicine in Palestine'; Daher-Nashif, 'Funerary Practices: Women: Palestine: Nineteenth to Early Twentieth Century', in S. Joseph (gen. ed.), Encyclopedia of Women and Islamic Cultures,. http://dx.doi.org/10.1163/1872-5309_ewic_COM_002100; N. Shalhoub-Kevorkian and S. Daher-Nashif, 'Liveliness of Death and Dying within the Palestinian Context: Dying in Jerusalem', in N. Hamadeh, N. El-Kadri and R. Debbas (eds), Marginalization in Arab Societies: Hindrance and Spur (Lebanon, Lebanese Association of Women Researchers, 2012), pp. 198-223 (in Arabic).

19 M. De-Paz, 'Medico-legal Autopsies in Israel', Medicine and Law, 26 (2002), 57-61.

20 Daher-Nashif, 'History and Present-Day Practice of Forensic Medicine in Palestine'.

21 Ibid.

22 J. Hiss, 'Forensic Medicine in Israel', Medicine and Law, 19 (1998), p. 71.

23 M. Al-Hadidi and N. Hamdi, Forensic Medicine and its Role in Implementing Criminal Law in Palestine (Bir-Zeit, Law School, Bir-Zeit University, 2003), 52-3.

24 G. Robinson, 'The Politics of Legal Reform in Palestine', Journal of Palestine Studies, 1 (1997), 51-60.

25 Al-Hadidi and Hamdi, Forensic Medicine and its Role, pp. 52-3.

26 According to Al-Hadidi, Hamdi, the legal system in the West Bank during this period was stable and transparent, and suited Palestinian society's norms and values as an Arab society; Al-Hadidi and Hamdi, Forensic Medicine and Its Role, p. 52.

27 Robinson, 'Politics of Legal Reform', 53.

28 For more information about that period, see Daher-Nashif, 'History and Present-Day Practice of Forensic Medicine in Palestine', 83.

29 Ibid.

30 J. Hiss, T. Kahana and B. Arensburg, 'Forensic Medicine in Israel', The American Journal of Forensic Medicine and Pathology, 18:2 (1997), 154-7.

31 Daher-Nashif, 'History and Present-Day Practice of Forensic Medicine in Palestine'.

32 Abu Dis is a Palestinian city located east of Jerusalem.

33 Al-Hadidi and Hamdi, The Role of Forensic Medicine; N. Al-Rayyess, Obstacles in Developing the Judicial System in Palestine (Ramallah, Palestine, Al-Haq Organisation, 2003).

34 Hiss, Kahana and Arensburg, 'Forensic Medicine in Israel', 154.

35 Ibid. 


\section{Suhad Daher-Nashif}

36 Means 'God is the greatest'.

37 J. Hiltermann, 'Deaths in Israeli Prisons', Journal of Palestinian Studies, 19:3 (1990), 101-10.

38 According to Israeli law, autopsies at the forensic medicine centre are performed only on cadavers whose family members authorise the procedure or when a court order has been issued. In cases of Palestinian martyrs or detainees, the Supreme Court issues the order for performing an autopsy without the family's consent.

39 Hiltermann, 'Deaths in Israeli Prisons', 102. See also B'Tselem report, 'The Interrogation of Palestinians During the Intifada: Ill-Treatment, Moderate Physical Pressure or Torture?' (Jerusalem, B’Tselem, 1991), pp. 32-3.

$40 \mathrm{Al}-\mathrm{Haq}$ is an independent Palestinian non-governmental human rights organisation based in Ramallah, West Bank. Established in 1979 to protect and promote human rights and the rule of law in the Occupied Palestinian Territory (OPT), the organisation has special consultative status with the United Nations Economic and Social Council (from Al-Haq website. For more information see: www.alhaq.org/about-Al-Haq/about-Al-Haq).

41 Hiltermann, 'Deaths in Israeli Prisons', 105. See also B'Tselem, 'The Interrogation of Palestinians During the Intifada, p. 35.

42 Following the Oslo accords, the Palestinian territory in the West Bank was divided into three administrative divisions: Areas A, B and C. Area A is exclusively administered by the Palestinian Authority. Area B is under Palestinian civil administration while Israel retains exclusive security control with limited cooperation from the Palestinian police. Area C, under full Israeli civil administration and security control, is the largest division in the West Bank, comprising 60 per cent of the territory.

43 This case is part of the data I collected during my ethnographic and archival fieldwork.

$44 \mathrm{Al}-$ Khalil (Hebron) is a Palestinian city located in the southern West Bank, $30 \mathrm{~km}$ (19 miles) south of Jerusalem.

45 L. Johansson, Beaten to Death: Omran Abu Hamdieh (Ramallah, Palestine, Al-Haq, 2003).

46 Ibid., p. 6.

47 Ibid., p. 7.

48 Daher-Nashif, 'The Palestinian Forensic Medicine Institute'.

49 Interview at the Palestinian Forensic Medicine Institute, April 2005.

50 Interview with the manager of Al-Haq Organization, Ramallah-Al Haq office, October 2006.

51 The Israeli Information Center for Human Rights in the Occupied Territories.

52 Johansson, Beaten to Death, p. 7.

53 On the issue of the Israeli structuralising of the Palestinian space see, J. Massad, The Persistence of the Palestinian Question: Essays on Zionism and the Palestinians (London and New York, Routledge, 2006) and O. Yiftachel, 'Territory as the Kernel of the Nation: Space, Time and Nationalism in Israel/Palestine', Geopolitics, 7:2 (2002), 219-21. 
54 Taken from the exhumation and autopsy report of Omran, which I received through doing my ethnographic fieldwork. The report is documented also in Johansson, Beaten to Death, pp. 25-8.

55 As documented in the report archived by the Al-Haq organisation.

56 Johansson, Beaten to Death, p. 8. Professor Thomsen's work took place under the auspices of the Centre for International Forensic Assistance (CIFA) and the University of Glasgow, but the report was signed by him exclusively.

57 A. Glikman, 'Policemen of the IDF Sentenced for Killing Palestinian', Ynet, 2 September 2008. [Accessed October 2017].

58 Prosecutor v Kordic and Cerkez, Case IT-95-14/2-T, Judgment, 26 Feb 2001, para 152. In Johansson, Beaten to Death, p. 11.

59 Prosecutor v. Zejnil Delalic et al., case No. IT-96-21-T, Judgment, 16 November 1998, para. 439. In Johansson, Beaten to Death, p. 12.

60 J. Derrida, Aporias, trans. T. Dutoit (Stanford, CA, Stanford University Press, 1993), p. 62.

61 N. Shalhoub-Kevorkian, Security, Theology, Surveillance and the Politics of Fear (Cambridge, Cambridge University Press, 2015), pp. 117-18.

62 The utterances and sayings of the Prophet Mohammad.

63 A. Al-Qassar, Autopsy Ruling between Shareea'a and Law (Lebanon, Dar Ibn Hazm, 1999), 30-1.

64 Ibid., 34.

65 Ibid., 35.

66 Ethnographic diary, May 2004.

67 Regarding that issue see A. Al-Shatshat, The History of Forensic Medicine in Islam and the Religious Permission for Transplanting Organs of Human Body (Libya, The General Cultural Council, 2006).

68 T. Asad, 'Anthropological Conceptions of Religion: Reflections on Geertz', MAN, 18:2 (1983), 237-59.

69 A. Ahmed, 'Death in Islam: The Hawkes Bay Case', MAN, 21:1 (1986), 120-34.

70 J. Baudrillard, Symbolic Exchange and Death (Thousand Oaks, CA, Sage, 1993), p. 130 . 